\title{
Studies on the Catalytic Properties of Partially Purified Alkaline Proteases from Some Selected Microorganisms
}

\author{
Titilayo Olufunke Femi-Ola ${ }^{a_{*}}$, and Oluwafemi Samuel Bamidele ${ }^{b}$ \\ ${ }^{1}$ Department of Microbiology, Ekiti State University, P. M. B. 5363, Ado-Ekiti, Nigeria \\ ${ }^{1}$ Department of Biochemistry, Federal University of Technology, P. M. B. 704 Akure, Nigeria \\ E.mail: titifemi2006@yahoo.com
}

Received 31 January 2012; Received in revised form 24 April 2012; Accepted 25 April 2012

\begin{abstract}
Aims: The research was done to study the conditions enhancing catalytic activities of alkaline proteases from Vibro sp., Lactobacillus brevis, Zymomonas sp., Athrobacter sp., Corynebacterium sp. and Bacillus subtilis.

Methodology and Results: The proteolytic enzymes were purified in 2-step procedures involving ammonium sulphate precipitation and sephadex G-150 gel permeation chromatography. The upper and lower limits for the specific activities of proteases from the selected microorganisms were estimated at 20.63 and 47.51 units $/ \mathrm{mg}$ protein with Zymomonas protease having the highest specific activity towards casein as its substrate and purification fold of 3.46 , while that of Lactobacillus brevis protease was 8.06. The native molecular weights of these active proteins ranged from 30.4 to 45.7 $\mathrm{kDa}$ with Athrobacter sp. protease having the highest weight for its subunits. The proteolytic enzymes had optimum $\mathrm{pH}$ range of 8 to 10 and temperature range of 50 to $62{ }^{\circ} \mathrm{C}$ accounting for the percentage relative activity range of 75 to $94 \%$ and 71 to $84 \%$ respectively. The activities of Lactobacillus brevis and Bacillus subtilis proteases were maximum at $\mathrm{pH} 9$ and 10 respectively. Lactobacillus brevis protease activity was maximum at temperature of $62{ }^{\circ} \mathrm{C}$, while beyond this value, a general thermal instability of these active proteins was observed. At above $70{ }^{\circ} \mathrm{C}$, the catalytic activities of Corynebacterium sp., Vibrio sp., Zymomonas sp. and Arthrobacter sp. proteases were progressively reduced over a period of 120 min of incubation, while Bacillus subtlis and Lactobacillus brevis proteases were relatively stable. Effect of metal ions was investigated on the catalytic activity of protease from the microorganisms. Lactobacillus brevis, Zymomonas sp., Arthrobacter sp., Corynebacterium sp. and Bacillus subtilis protease activities were strongly activated by metal ions such as $\mathrm{Ca}^{+2}$ and $\mathrm{Mg}^{+2}$. Enzyme activities were inhibited strongly by $\mathrm{Cu}^{2+}$ and $\mathrm{Hg}^{2+}$ but were not inhibited by ethylene diamine tetra acetic acid (EDTA), while a slight inhibition was observed with $\mathrm{K}^{+}, \mathrm{Na}^{+}$and $\mathrm{Fe}^{2+}$.

Conclusion, significance and impact of study: The outcome of this present study indicated useful physico-chemical properties of proteolytic enzymes that could be of biotechnological use in enhancing enzyme catalytic efficiency.
\end{abstract}

Keywords: alkaline protease, catalytic activities, microorganisms, optimum conditions

\section{INTRODUCTION}

Proteases are hydrolytic enzymes which split peptide bonds releasing oligopeptides or free amino acids. They perform both degradative and synthetic functions (Degering et al., 2010). Proteolytic enzymes are ubiquitous in occurrence, being found in all living organisms and are essential for their growth and differentiation. Although, there are many microbial sources available for producing proteases, only a few are recognized as commercial producers (Gupta et al., 2002). Mussarat et al. (2008) reported that many different types of extracellular hydrolytic and non- hydrolytic enzymes are produced by microorganisms e.g Actinoplanes sp., Arthrobacter sp., Aspergillus sp., Bacillus cereus, Bacillus coaglulans, Bacillus subtlis, Candida sp., Clostridium sp., Lactobacillus sp., Penicillium sp., Pseudomonas sp., Rhizopus sp., Streptococcus sp., Streptomyces sp. Alkaline protease (EC.3.4.21-24, 99) is active in a neutral to alkaline $\mathrm{pH}$ range and has been shown to have either a serine centre (serine protease) or metallotype (metalloprotease). Many different environments have been explored and exploited for alkaline protease production from Bacillus species. According to Gupta et al. (2002), B. licheniformis, B. subtilis, $B$. amyloliquefaciens and $B$. majovensis were reported to be the most potential alkaline protease producing Bacillus strains.

The production and catalytic activity of protease are influenced by altered conditions such as $\mathrm{pH}$, temperature, ion concentration, substrate concentration. Alkaline proteases have been satisfactorily used in leather processing, meat tenderization, protein recovery and solubilisation (Johnvesly and Naik, 2001), and detergent application (Najafi and Deobagkar, 2005). In recent years a number of studies have been conducted to characterize alkaline proteases from different microorganisms including bacteria, moulds, yeasts and mammalian tissues (WeiHua, 2007). Microorganisms represent an excellent 
source of protease owing to their broad biochemical diversity and susceptibility to genetic manipulation that are desirable for various applications. In the present study, we report the optimum physicochemical properties enhancing the catalytic activities of partially purified protease from different isolates of microorganisms.

\section{MATERIALS AND METHODS}

\section{Microorganisms}

Vibro sp., Lactobacillus brevis, Zymomonas sp., Athrobacter sp., Corynebacterium sp. and Bacillus subtilis, used in the present study, were isolated from the gut of kola nut weevil (Balanogastris kolae). Cultures were maintained on Nutrient agar slants.

\section{Qualitative test for protease}

Proteolytic activities of Vibro sp., Lactobacillus brevis, Zymomonas sp., Athrobacter sp., Corynebacterium sp. and Bacillus subtilis were detected on the basis of appearance of clear zones around the bacterial colonies. Luria casein agar (1\%) plates were used.

\section{Quantitative test for protease}

The culture conditions and media for growth of the alkaline protease by the microorganisms were optimized to give maximum production. The basal medium consists (g/L): $\mathrm{K}_{2} \mathrm{HPO}_{4}, 1.5 ; \mathrm{KH}_{2} \mathrm{PO}_{4}, 0.5 ; \mathrm{MgSO}_{4}, 0.05 ; \mathrm{NaCl}_{2}$, 1.5; $\left(\mathrm{NH}_{4}\right)_{2} \mathrm{SO}_{4}, 1.0 ; \mathrm{CaCl}_{2}, 0.2 ; \mathrm{FeSO}_{4}, 0.2 ;$ sucrose; 0.5 yeast extract, 0.5 and $1 \%$ casein was prepared in a 250 $\mathrm{ml}$ flask each for the microorganisms and was adjusted by using $0.1 \mathrm{M}$ sodium hydroxide and $0.1 \mathrm{M}$ acetic acid to $\mathrm{pH}$ 8. The medium was autoclaved at $121^{\circ} \mathrm{C}, 15 \mathrm{psi}$ for 20 min. Oven sterilized, $3 \mathrm{~mL}$ of $20 \%$ glycerol solution was added to the medium aseptically. Each of the selected microorganisms was inoculated in the medium separately and the flasks were kept in shaking incubator at $37^{\circ} \mathrm{C}$ with $200 \mathrm{rpm}$. Samples were drawn from the flasks at intervals of $12 \mathrm{~h}$ for a period of $72 \mathrm{~h}$ and centrifuged at $3000 \mathrm{rpm}$ for $30 \mathrm{~min}$ at $4^{\circ} \mathrm{C}$. Cell free supernatant corresponding to growth phase was used as the crude enzyme for assay and further analysis. The method of Fugiwara and Yamamoto (1993) was used for the determination of protease activity in culture supernatant with casein as the substrate. One unit of enzyme activity was defined as the amount of enzyme which releases a micromole tyrosine under standard assay condition of 45 ${ }^{\circ} \mathrm{C}, \mathrm{pH} 8.5$ and reaction time one hour. Lowry method was used for protein determination (Lowry et al., 1951)

\section{Enzyme Purification}

Ammonium sulphate precipitation: The supernatant was fractionated by precipitation with ammonium sulphate between $50 \%$ and $70 \%$ of saturation. All subsequent steps were carried out at $4{ }^{\circ} \mathrm{C}$. The protein pellet obtained was re-suspended in $10 \mathrm{mM}$ Tris- $\mathrm{HCl}$ buffer, $\mathrm{pH} 7.8$, and dialyzed against the same buffer for $24 \mathrm{~h}$.
Sephadex G-100 gel filtration chromatography: The dialysed protein solution from ammonium sulphate precipitation was loaded onto a column of sephadex G$100(1.5 \times 75 \mathrm{~cm})$ equilibrated with $10 \mathrm{mM}$ Tris- $\mathrm{HCl}$ buffer, $\mathrm{pH}$ 7.8. The column was eluted at a flow rate of 20 $\mathrm{mL} / \mathrm{h}$ with the same buffer. Five millilitre fractions were collected and subsequently assayed for protease activity.

Estimation of native molecular weight: Sephadex G100 column was standardised with $3 \mathrm{mg} / \mathrm{mL}$ protein markers (creatinephosphokinase 81,000; bovine serum albumin 68,000; ovalbumin 45,000; and alpha chymotrypsinogen 24,700 ) and blue dextran was used to determine the void volume of the column. The molecular weight was determined from a linear semilogarithmic plot of $V_{e} / V_{o}$ against relative molecular weight. $V_{e}$ is the elution of protein that is measured from the start of the sample application to the inflection point half height rising of the elution peak. $V_{o}$ is the void volume, which is the elution volume of blue dextran.

\section{Estimation of optimum $\mathrm{pH}$}

The effect of $\mathrm{pH}$ on the enzyme activity was determined from different $\mathrm{pH}$ values of assay medium using phosphate (5.0 to 7.0), Tris- $\mathrm{HCl}$ (8.0), and glycine- $\mathrm{NaOH}$ (9.0 to 12.0$)$ buffers. The enzyme was incubated for 20 min and enzyme activity was estimated before and after the treatment under standard assay conditions.

\section{Thermal stability}

Effect of temperature on the enzyme activity was determined at different temperatures ranging from $30^{\circ} \mathrm{C}$ to $90{ }^{\circ} \mathrm{C}$. The enzyme was incubated for $20 \mathrm{~min}$ and enzyme activity was estimated before and after the treatment under standard assay conditions. The thermal stability of partially purified protease was determined at different temperatures of $60{ }^{\circ} \mathrm{C}, 70{ }^{\circ} \mathrm{C}$ and $80^{\circ} \mathrm{C}$ for a period of $120 \mathrm{~min}$ of incubation and enzyme activity was estimated before and after the treatment under standard assay conditions at intervals of $15 \mathrm{~min}$.

\section{Effect of metal ions}

The effect of metal ions was tested on the activity of partially purified protease with $20 \mathrm{mM}$ chloride solutions of $\mathrm{Na}, \mathrm{K}, \mathrm{Ca}, \mathrm{Mg}, \mathrm{Cu}, \mathrm{Fe}$, and $\mathrm{Hg}$. The enzyme was incubated for $20 \mathrm{~min}$ and enzyme activity was estimated before and after the treatment under standard assay conditions.

\section{RESULTS AND DISCUSSION}

\section{Qualitative and quantitative analysis}

The preliminary studies on the production of protease from Vibro sp., Lactobacillus brevis, Zymomonas sp., Athrobacter sp., Corynebacterium sp. and Bacillus subtilis revealed that all microorganisms used for test produced clear zones around the bacterial colonies on $1 \%$ casein 
agar plate at $37{ }^{\circ} \mathrm{C}$ after $24 \mathrm{~h}$ of incubation but the clear zones were different in diameter with Vibro sp., Lactobacillus brevis, and Bacillus subtilis having wider area than Zymomonas sp., Athrobacter sp. and Corynebacterium sp. The different patterns of clear zones could largely be due to different rates of substrate hydrolysis and its utilization by the various microbial cells. Production of protease by these microbes were at their peaks during the growth phases which range from 36 to $48 \mathrm{~h}$ of incubation accounting for maximum activity range of 102 to 244 units $/ \mathrm{mL}$. Suggestively, Vibro sp, Lactobacillus brevis, and Bacillus subtilis were observed to better utilize casein as substrate for maximum production of protease. Similar results were reported by Adinarayana et al. (2003) observed maximum growth and enzyme production at $48 \mathrm{~h}$ of incubation.

\section{Purification of extracellular alkaline protease from the microbes}

Crude enzymes of the microbes were purified in 2-step procedures involving ammonium sulphate precipitation and sephadex G-150 gel permeation chromatography. The microbes produced a characteristic elution profiles with different activity peaks (results not shown), but the summary of purification steps are shown in Tables 1, 2 and 3. The total enzyme activities (Table 1) of Bacillus subtilis, Lactobacillus brevis and Vibro sp. were higher than that of Zymomonas sp., Athrobacter sp. and Corynebacterium sp. with Lactobacillus brevis almost thrice the total enzyme activity of Corynebacterium sp. Zymomonas sp. and Athrobacter sp. were almost equal in their total enzyme activities, while Bacillus subtilis was almost $90 \%$ of the total enzyme activity of Vibro sp. In the same vein, the corresponding total enzyme proteins (Table 2) of the microbes showed significant differences. Vibro sp. and Bacillus subtilis were almost equal in their total enzyme proteins while Athrobacter sp. and Corynebacterium sp. showed the same results. The total enzyme activity of Lactobacillus brevis was the highest and Zymomonas sp., the least. On the contrary, the values of specific enzyme activities of the microbial proteases (Table 3 ) toward casein as the substrate were different from the values for total enzyme activities and total enzyme proteins. The specific enzyme activity of Zymomonas sp. protease was the highest, while Vibro sp. and Corynebacterium sp. were equal and Bacillus subtilis was the least. In addition, the specific activities of Lactobacillus brevis and Athrobacter sp. proteases were almost 62 and $73 \%$ of Zymomonas sp. protease. The upper and lower limits for the specific enzyme activities of the selected microbial proteases were estimated as 20.63 and $47.51 \mathrm{units} / \mathrm{mg}$ protein with Zymomonas sp. protease having the highest specific activity towards casein as its substrate and purification fold of 3.46. However Lactobacillus brevis had a purification fold of 8.06. The purification results suggest different rates of production of microbial proteoltyic enzymes in response to the amount of available protein substrates and different degrees of substrate breakdown and utilization with the corresponding substrate turnover rates. Thermostable alkaline protease from Bacillus subtilis $\mathrm{PE}-11$ was purified in a similar way (Adinarayana et al., 2008).

Table 1: Total activities of partially purified microbial proteases

\begin{tabular}{lc}
\hline Micoorganism protease & Total activity (units) \\
\hline Vibro sp & 11077 \\
Lactobacillus brevis & 16047 \\
Zymomonas sp. & 8357 \\
Athrobacter $\mathrm{sp}$. & 8364 \\
Corynebacterium sp. & 5925 \\
Bacillus subtilis & 9896 \\
\hline
\end{tabular}

Table 2: Total protein of partially purified microbial proteases

\begin{tabular}{lc}
\hline Micoorganism protease & Total protein $\mathbf{( m g )}$ \\
\hline Vibro sp. & 520.3 \\
Lactobacillus brevis & 550.35 \\
Zymomonas sp. & 188.7 \\
Athrobacter sp. & 253.2 \\
Corynebacterium $\mathrm{sp}$. & 269.70 \\
Bacillus subtilis & 460.2 \\
\hline
\end{tabular}

Table 3: Specific activities of partially purified microbial proteases

\begin{tabular}{lc}
\hline Micoorganism protease & $\begin{array}{c}\text { Specific activity } \\
\text { (units/mg) }\end{array}$ \\
\hline Vibro sp. & 21.29 \\
Lactobacillus brevis & 29.15 \\
Zymomonas sp. & 48.54 \\
Athrobacter sp. & 33.03 \\
Corynebacterium sp. & 21.96 \\
Bacillus subtilis & 20.35 \\
\hline
\end{tabular}

Table 4: Native molecular weights of partially purified microbial proteases

\begin{tabular}{lc}
\hline Micoorganism protease & Daltons \\
\hline Vibro sp. & 22357 \\
Lactobacillus brevis & 33200 \\
Zymomonas sp. & 20458 \\
Athrobacter sp. & 35716 \\
Corynebacterium sp. & 22886 \\
Bacillus subtilis & 26515 \\
\hline
\end{tabular}

Table 5: Optimum $\mathrm{pH}$ of partially purified microbial proteases

\begin{tabular}{lc}
\hline Micoorganism protease & $\mathbf{p H}$ \\
\hline Vibro sp. & 8.0 \\
Lactobacillus brevis & 9.0 \\
Zymomonas sp. & 8.0 \\
Athrobacter sp. & 8.0 \\
Corynebacterium sp. & 9.0 \\
Bacillus subtilis & 10.0 \\
\hline
\end{tabular}

\section{Native molecular weight}

Important differences exist among the molecular weights of the proteases of the bacterial isolates studied as shown 
in Table 4. The native molecular weight was determined from sephadex G-100 column standardized with some known standard protein markers and the result indicated weight values ranging from 30.4 to $45.7 \mathrm{kDa}$ with Athrobacter sp protease having the highest weight for its subunits. The molecular weights of Vibro sp., Zymomonas $\mathrm{sp}$. and Corynebacterium sp. proteases were almost equal, while Lactobacillus brevis and Bacillus subtilis proteases ranked second and third respectively compared with the molecular weight of Athrobacter sp. protease. These variations in the molecular weights of the microorganisms are probably due to variations in the genetic makeup of their cells as microbes have different rates of gene expression for different rates of gene activation. The aggregation of protein subunits could also be responsible for various sizes of tertiary structures of enzymes (Voet and Voet, 2004).

\section{Optimum pH, optimum temperature and thermal stability}

The partially purified proteolytic enzymes from these selected microorganisms had optimum $\mathrm{pH}$ range of 8.0 to 9.0 (Table 5) which accounted for a range of 75 to $94 \%$ relative activity with casein as substrate. Vibro sp., Zymomonas sp. and Athrobacter sp. proteases were observed to have their maximum percentage relative activities at optimum $\mathrm{pH}$ of 8.0 while Lactobacillus brevis and Corynebacterium sp proteases at higher $\mathrm{pH}$ value of 9.0 and Bacillus subtilis at $\mathrm{pH} 10.0$. Table 6 shows the optimum temperatures of Vibro sp., Lactobacillus brevis; Zymomonas sp., Athrobacter sp., Corynebacterium sp., and Bacillus subtilis protease activities. The maximum percentage relative activities (71 to $84 \%$ ) of the microbial proteases were observed at temperature range of 50 to 62 ${ }^{\circ} \mathrm{C}$. The optimum temperatures of Vibro sp., Zymomonas $s p$, Corynebacterium $\mathrm{sp}$ and Bacillus subtilis protease activities were the same while Athrobacter sp. and Lactobacillus brevis proteases activities were at 60 and 62 ${ }^{\circ} \mathrm{C}$. Beyond these valves, a general thermal instability of these active proteins was observed (Figure 1).

At above $70{ }^{\circ} \mathrm{C}$ (Figure 2), the proteolytic activities of Corynebacterium sp and Bacillus subtilis, Zymomonas sp. and Athrobacter sp. were drastically reduced over a period of 120 min of incubation but the activities of Vibro $\mathrm{sp}$. and Lactobacillus brevis proteases were relatively stable. Enzymes generally are amphoteric molecules containing a large number of acidic and basic groups located mainly on their surfaces. The charges on these groups will vary according to their acid dissociation constants and with the $\mathrm{pH}$ of their environment. This will affect the total net charge of the enzymes and the distribution of charges on their exterior surfaces, in addition to the reactivity of the catalytic active groups. These effects are especially important in the neighbourhood of the active sites, which will overall affect the activity, structural stability and solubility of the enzyme (Price and Steven, 1990). Alkaline proteases of the genus Bacillus have been shown to have maximum catalytic activity at optimum $\mathrm{pH}$ and a good stability at high alkaline $\mathrm{pH}$ values. The results of $\mathrm{pH}$ range of 8 to 12 (Gupta et al., 2002); 8 to 11 (Adinarayana et al., 2003) for alkaline protease producing bacteria were similar to the values obtained in the present study. However, contrasting $\mathrm{pH}$ values have been reported by several authors (Mussarat et al., 2008; Kumar et al., 1999) for Bacillus alkaline proteases.

Table 6: Optimun temperature of partially purified microbial proteases

\begin{tabular}{ll} 
Micoorganism protease & Temperature $\left({ }^{\circ} \mathbf{C}\right)$ \\
\hline Vibro sp. & 50 \\
Lactobacillus brevis & 60 \\
Zymomonas sp. & 50 \\
Athrobacter $\mathrm{sp}$. & 60 \\
Corynebacterium $\mathrm{sp}$. & 50 \\
Bacillus subtilis & 50 \\
\hline
\end{tabular}

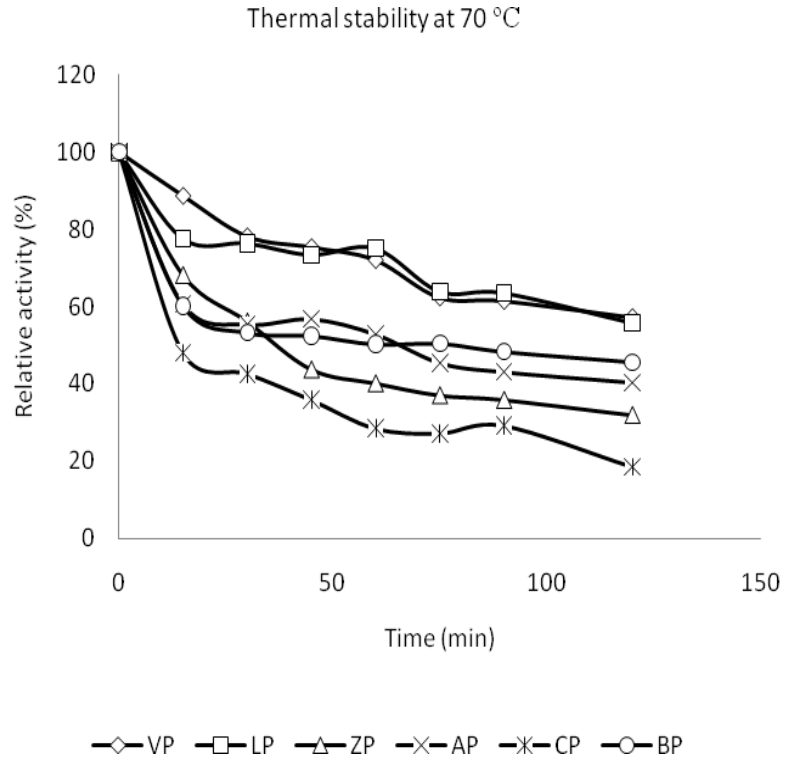

Figure 1: Thermal stability of partially purified microbial proteases at $70^{\circ} \mathrm{C}$

Vp-Vibro sp protease;

Lp-Lactobacillus brevis protease;

Zp- Zymomonas protease;

Ap-Athrobacter protease;

Cp-Corynebacterium sp protease;

$\mathrm{Bp}$ - Bacillus subtilis protease

Changes in temperature of the environment in which enzyme exert its action on substrate greatly influence enzyme stability and catalysis. Enzymes provide a compact structure that is not easily denatured by this external environment factor but at above or below the optimum temperature range, a loss in the catalytic activity of the active protein is seen due to the unfolding state of the tertiary structure of the enzyme. Several investigators (Gupta and Beg, 2003; Joo et al., 2003; Oberoi et al., 2001) have reported the optimum temperature of bacillus 
Table 7: Effect of metal ions on the catalytic activities of partially purified microbial protease

\begin{tabular}{lccc}
\hline \multirow{2}{*}{ Microorganism } & \multicolumn{3}{c}{ Metal ions } \\
\cline { 2 - 4 } & Protease activators & Weak inhibitors & Strong inhibitors \\
\hline Vibrio sp. & $\mathrm{K}^{2+}$ & $\mathrm{Mg}^{2+}, \mathrm{Ca}^{2+}, \mathrm{Na}^{+}$ & $\mathrm{Cu}^{2+}, \mathrm{Hg}^{2+}$ \\
Lactobacillus brevis & $\mathrm{Ca}^{2+}$ & $\mathrm{K}^{+}, \mathrm{Mg}^{2+}, \mathrm{Fe}^{2+}$ & $\mathrm{Cu}^{2+}, \mathrm{Hg}^{2+}$ \\
Zymomonas sp. & $\mathrm{Mg}^{2+}$ & $\mathrm{K}^{+}, \mathrm{Ca}^{2+}$ & $\mathrm{Cu}^{2+}, \mathrm{Hg}^{2+}$ \\
Arthrobacter sp. & $\mathrm{Ca}^{2+}, \mathrm{Mg}^{2+}$ & $\mathrm{Na}^{+}, \mathrm{K}^{+}$ & $\mathrm{Cu}^{2+}, \mathrm{Hg}^{2+}, \mathrm{Fe}^{2+}$ \\
Corynebacterium $\mathrm{sp}$. & $\mathrm{Ca}^{2+}, \mathrm{Mg}^{2+}$ & $\mathrm{Na}^{+}, \mathrm{K}^{+}$ & $\mathrm{Cu}^{2+}, \mathrm{Hg}^{2+}$ \\
Bacillus subtilis & $\mathrm{Ca}^{2+}, \mathrm{Mg}^{2+}$ & $\mathrm{Fe}^{2+}$, & $\mathrm{Cu}^{2+}, \mathrm{Hg}^{2+}$ \\
\hline
\end{tabular}

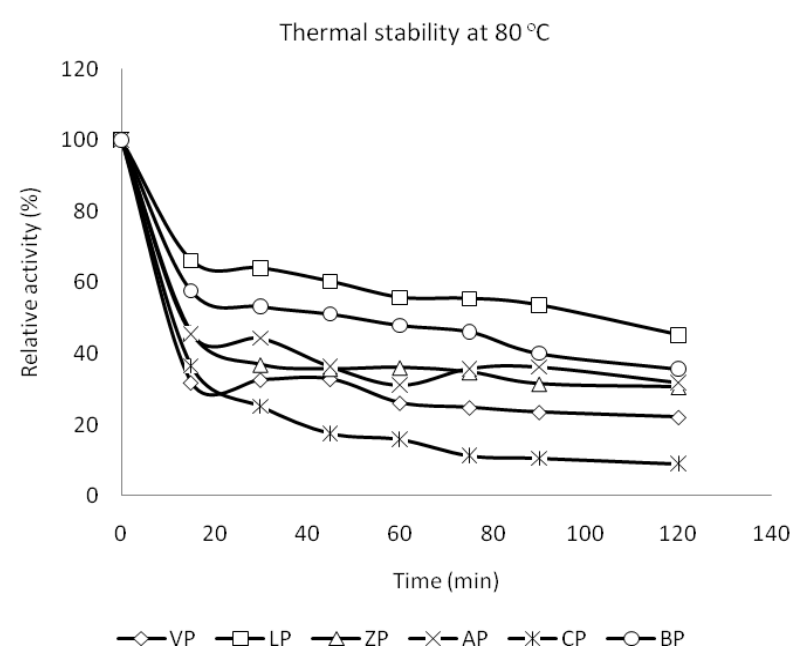

Figure 2: Thermal stability of partially purified microbial protease activity at $80^{\circ} \mathrm{C}$

Vp-Vibro $s p$ protease;

Lp-Lactobacillus brevis protease;

Zp- Zymomonas protease;

Ap-Athrobacter protease;

Cp- Corynebacterium sp protease;

Bp- Bacillus subtilis protease

species alkaline protease as $60 \%$ and their results were in agreement with what is obtained in the present study.

\section{Effects of metal ions}

The effect of metal ions $\left(\mathrm{Ca}^{2+} \mathrm{Mg}^{2+}, \mathrm{K}^{+}, \mathrm{Na}^{+}, \mathrm{Fe}^{2+}, \mathrm{Cu}^{2+}\right.$, and $\mathrm{Hg}^{2+}$ ) and metal chelating agent (EDTA) were tested on the catalytic activities of Vibro sp, Lactobacillus brevis, Zymomonas sp, Athrobacter, Corynebacterium sp, and Bacillus subtilis proteases (Table 7). The metal ions had either stimulatory, weak inhibitory or strong inhibitory effects on the activities of the microbial proteolytic enzymes. $\mathrm{Ca}^{2+}$ and $\mathrm{Mg}^{2+}$ were generally observed to have stimulatory effects on the catalytic activities of Lactobacillus brevis, Zymomonas sp., Arthrobacter sp., Corynebacterium sp. and Bacillus subtilis proteases with a range of percentage relative activity of 101-108\% while the activity of Vibrio $\mathrm{sp}$ protease was stimulated by $\mathrm{K}^{+}$but weak inhibitory effects on the activities of Zymomonas sp. and Vibrio sp proteases were seen with $\mathrm{Ca}^{2+}$. Other metals showing weak inhibitory effects on the microbial protease activities were $\mathrm{K}^{+}, \mathrm{Na}^{+}$and $\mathrm{Fe}^{2+}$. Generally, there were significant loss of catalytic activities of Vibro sp, Lactobacillus brevis, Zymomonas sp, Athrobacter, Corynebacterium $\mathrm{sp}$, and Bacillus subtilis proteases with $\mathrm{Cu}^{2+}$ and $\mathrm{Hg}^{2+}$. The Stimulatory effect observed was possibly an indication of protective properties of metal ions when they form bond with catalytic groups on the active site of enzymes to position the active site for binding of substrate and stabilize the enzyme-substrate complex for product formation. On the other hand, the inhibitory effect is possibly due to the redox ability of some metal ions as they participate in abstracting electrons from the interaction between the enzyme active groups and substrates thereby causing a kind of distortion in either enzyme structure or nature of substrate, overall enzymesubstrate complex are prevented and no product formation. Similar stimulatory and inhibitory effects of some metal ions were reported by Adinarayana et al. (2003) and Sookkeo et al. (2000).

\section{CONCLUSION}

The physico-chemical properties affecting catalytic activities of some partially purified microbial proteases were highlighted. Vibro $s p$; Lactobacillus brevis; Zymomonas sp; Athrobacter sp; Corynebacterium sp; and Bacillus subtilis proteases were shown to have varying total proteins, total activities, specific activities and native molecular weights. Other properties include alkaline $\mathrm{pH}$ range, higher temperature range and metal ion activators and inhibitors. These properties indicated possiblilty of proteases from various (sources of) strains of microorganisms for enzyme biotechnological use in enhancing catalytic efficiency of industrial enzymes.

\section{REFERENCES}

Adinarayana, K., Ellaiah, P. and Prasad, D.S. (2003). Purification and partial characterization of thermostable serine alkaline protease from a newly isolated Bacillus subtilis PE-11. AAPS Pharmaceutical Science Technician 4, 56-63.

Fugiwara, N. and Yamamoto, Z. (1993). Production of alkaline protease in a low-cost medium by alkalophilic Bacillus sp. and properties of the enzyme. Journal of Fermentation Technology 65, 345-351.

Degering, C., Eggert, T., Pul, M., Bongaerts, J., Evers, S., Maurer, H. H. and Jaeger, K. E. (2010). Optmization of protease secretion in Bacillus subtilis and Bacillus licheniformis by screening of 
homologous and heterologous signal peptides. Applied Environmental Microbiology 76, 6370-6376.

Gupta, R. and Beg, Q. K. (2003). Purification and characterization of an oxidation stable, thioldependent serine alkaline protease from Bacillus moavensis. Enzyme and Microbial Technology 32, 294-301.

Gupta, R., Beg, Q. K., Lorenz, P. (2002). Bacteria alkaline protease: molecular approaches and industrial application. Applied Microbiology and Biotechnology 59, 15-32.

Johnvesly, B. and Naik, G. R. (2001). Studies on production of thermostable alkaline protease from thermophilic and alkaliphilic Bacillus sp. JB-99 in chemically defined medium. Process Biochemistry 37, 139-152.

Joo, H. S., Kumar, C. G., Park, G. C., Paik, S.R. and Chang, C. S. (2003). Oxidant and SDS-stable alkaline protease from Bacillus clausii 1-52: production and some properties. Journal of Applied Microbiology 95, 267-274.

Kumar, C. G. and Takagi, H. (1999). Microbial alkaline proteases from bio-industrial viewpoint. Biotechnology Advances 17, 561-594.

Kunitz, N. (1965). Methods of enzymatic analysis (2 $2^{\text {nd }}$ Edition). Verlag Chemical Academic Press. New York, London pp. 807-814.

Lowry, O. H., Rosebrough, N. J., Farr, A. L. and Randall, R. J. (1951). Protein determination. Journal Biological Chemistry 193, 265-275.

Mussarat, S., Aamer, A. S., Abdul, H. and Fariha, H. (2008). Influence of culture conditions on production and activity of protease from Bacillus subtilis BS1. Pakistan Journal of Botany 40 (5), 2161 2169.

Najafi, M. F. and Deobagkar, D. (2005). Potential application of protease isolated from Pseudomonas aeruginosa PD 100. Journal of Biotechnology 8, 370374.

Oberoi, R., Beg, Q. K., Puri, S., Saxena, R. K. and Gupta, R. (2001). Characterization and wash performance analysis of an SDS-stable alkaline protease from a Bacillus sp. Journal of Microbiology and Biotechnology 17, 493-499.

Price, N. C. and Steven, L. (1982). Fundamentals of Enzymology. Oxford University Press, Oxford, 454pp.

Sookkeo, B., Sinchaikul, S., Phutrakul, S. and Chen, S.T. (2000). Purification and characterization of thehighly thermostable protease from Bacillus sterothermophilus TLS33. Protein Expression and Purification 20 (2), 142-51.

Voet, D. and Voet, J.G. (2004). Biochemistry $3^{\text {rd }}$ Edition. John Wiley and Sons Inc. USA. 1591pp.

Wei-Hua, C. (2007). Optimization of extracellular alkaline protease production from species of Bacillus. Journal Industrial Microbiology and Biotechnology 34, 241245. 